\section{Clinicopathological study of salivary gland tumors: an assessment of 303 patients}

\author{
Estudo clinicopatológico de tumores de glândulas \\ salivares: avaliação de 303 pacientes
}

\author{
${ }^{1}$ Centro de Ciências da \\ Saúde, Universidade Federal \\ do Rio Grande do Norte, \\ Natal, Brasil. \\ 2 Departamento de \\ Estatística, Universidade \\ Federal do Rio Grande do \\ Norte, Natal, Brasil. \\ ${ }^{3}$ Hospital Dr. Luiz Antônio, \\ Liga Norte-Rio-Grandense \\ Contra o Câncer, Natal, \\ Brasil. \\ Correspondence \\ M. L.S. A. Morais \\ Centro de Ciências da Saúde \\ Universidade Federal do \\ Rio Grande do Norte. \\ Rua General Gustavo \\ Cordeiro de Farias s/n, Natal, \\ RN 59010-180, Brasil. \\ lourd@unp.br
}

\section{Abstract}

Salivary gland neoplasms are remarkable for their histological diversity and several studies point to their varied occurrence in the population. Clinical aspects were histologically assessed to determine possible associations and define parameters to differentiate benign and malignant neoplasms. The case files of patients diagnosed with epithelial salivary gland tumors between 1989 and 2005 were reviewed. A majority (71\%) of the 303 salivary gland tumors studied were benign and pleomorphic adenoma were found to be most common. Mean ages for patients with benign and malignant tumors were 49.2 and 58.5 years, respectively. A statistically significant difference between these tumors was observed for the following variables: mean age, tumor size and disease duration. A correlation was found between histological diagnosis and tumor consistency. The data presented here corroborate a number of previous studies and are therefore relevant in understanding the diverse characteristics exhibited by these tumors.

Salivary Gland Neoplasms; Salivary Gland; Neoplasms; Adult Health
Maria de Lourdes Silva de Arruda Morais 1

Paulo Roberto Azevedo 2

Cyntia Helena Carvalho 1

Lélia Medeiros 3

Tirzah Lajus 3

Antonio de Lisboa Lopes Costa 1

\section{Introduction}

Oral cancer is a major problem in oral health because it continues to exhibit high incidence and mortality rates throughout Brazil. The National Cancer Institute estimates that 14,120 new cases of oral cancer alone were diagnosed in 2010. Of all oral cancers, salivary gland tumors represent a small percentage 1 .

Most series reported in the literature include both major and minor salivary gland tumors, making it difficult to evaluate their real frequency and site distribution 2 . They are relatively rare, accounting for approximately $3 \%$ to $10 \%$ of all head and neck tumors 3,4 , and are more commonly found in the parotid gland 3 . The parotid, submandibular and minor salivary glands of the palate are significantly affected 5 .

More than $80 \%$ of parotid tumors are benign. More than $50 \%$ of those in the submandibular or sublingual glands are malignant. They are usually asymptomatic. However, a number of clinical predictors suggest malignancy, such as rapid growth, pain, facial nerve involvement and cervical adenopathy. Trismus, cutaneous ulceration and fistula tracts may be present 6 .

Salivary gland neoplasms are remarkable for their histological diversity and pose a particular challenge to the pathologist because of their complex classification and the rarity of several varieties 7. Pleomorphic adenoma and mucoepidermoid carcinoma are the two most common 2 . 
The purpose of the present work is to assess the distribution of benign and malignant epithelial salivary gland tumors at a cancer treatment center in Natal, Rio Grande do Norte State, Brazil. The clinical aspects and histological findings were analyzed to determine possible associations.

\section{Materials and methods}

In this clinical study we reviewed the clinical records of all patients treated between January 1, 1989 and December 31, 2005 at a cancer center located in the city of Natal. Patients diagnosed with either benign or malignant epithelial salivary gland tumors were selected according to the World Health Organization (WHO) histological classification of salivary gland tumors 7 . Patients were divided into two main groups: malignant and benign.

The data were obtained from medical records by a single examiner, who gathered information recorded in the first clinical diagnosis of each patient, such as age, gender, lesion site, histopathological diagnosis (performed by a single experienced pathologist), tumor size in $\mathrm{cm}$ (by clinical examination), disease duration in years (obtained from the patient's clinical history), pain (present/absent), ulceration (present/absent, by clinical examination), growth (present/ absent), tumor consistency, classified by physical examination (hard, fixed, elastic and stony), lesion attachment, determined by physical examination (mobile/fixed) and presence of local and distant metastasis. All the cases used in this study were diagnosed and treated at the leading state cancer center.

The student's t-test was applied to compare average ages between malignant and benign tumors, as well as between genders for malignant and benign tumors separately and combined. The same test was used to compare average tumor size and disease duration between the neoplasias. Chi-square tests were carried out to evaluate the association between histopathological diagnosis and variables such as pain, ulceration, growth, tumor consistency and attachment within malignant and benign tumors. Correlation tests between some of the variables (histological diagnosis, disease duration and tumor size) were also performed. The significance level was set at 0.05 for all the tests.

This study was approved by the Ethics Committee of the Federal University in Rio Grande do Norte (protocol no. 115/05).

\section{Results}

During the study period (1989 to 2005), 62,930 medical records were evaluated. Of the 303 epithelial salivary gland tumors found, 215 (71\%) were benign and 88 (29\%) were malignant, representing a ratio of 2.4:1, respectively. Women were more affected by both benign and malignant tumors. Statistical analysis showed no difference in average age between genders ( $p>0.05$ ) for benign and malignant salivary gland tumors considered separately and combined (Table 1). The difference in average age between benign and malignant tumors was found to be statistically significant $(\mathrm{p}<0.001)$, where ages ranged from 12 to 92 years (average age of 49.2 years) for benign tumors and 9 to 94 years (average age of 58.5 years) for malignant ones.

The frequency distribution of benign and malignant salivary gland tumors according to tumor site is presented in Table 2. We observed that major salivary gland tumors were more frequent (87.8\%) than their minor counterparts $(12.2 \%)$, regardless of gender. Major salivary gland tumors were more common in females than in males, with the parotid most affected.

The frequency of histological types of salivary gland tumors is shown in Table 3. Pleomorphic adenoma was the most frequently found benign tumor, whereas mucoepidermoid carcinoma was the most common malignant tumor primarily affecting the parotid. Some histological tumor types were exclusive to the major salivary gland, such as Warthin's tumor, carcinoma ex pleomorphic adenoma, oncocytoma and acinic cell carcinoma. No tumors were found in the sublingual gland.

Possible associations with histopathological diagnosis were analyzed for signs and symptoms (pain, ulceration, growth, consistency and attachment) exhibited by all the benign and malignant tumors. In relation to the malignant tumors, a significant association was found between histopathological diagnosis and variable consistency ( $\mathrm{p}=0.015$ ) (Table 4 ), with hard, unyielding consistency more common in mucoepidermoid carcinoma. No significant association was observed $(p>0.05$ ) for any other variable. With respect to the benign and malignant tumors combined, we observed an association between histopathological diagnosis and t variable ulceration ( $p=0.049$ ) and between histopathological diagnosis and consistency ( $\mathrm{p}<0.001$ ) (Table 4). Elastic consistency was most common in the pleomorphic adenoma and hard consistency in the mucoepidermoid carcinoma. An association was also found between histopathological diagnosis and attachment $(\mathrm{p}<0.001)$ (Table 4). Mobile attachment was more frequent in 
Comparison of average age between females and males with respect to salivary gland tumors.

\begin{tabular}{|c|c|c|c|c|c|c|}
\hline Tumor & Ratio F:M & $\begin{array}{c}\text { Age } \\
\text { ranges }\end{array}$ & $\begin{array}{c}\text { Total } \\
\text { (average } \pm \mathrm{SD} \text { ) }\end{array}$ & $\begin{array}{c}\text { Females } \\
\text { (average } \pm S D \text { ) }\end{array}$ & $\begin{array}{c}\text { Males } \\
\text { (average } \pm \text { S.D) }\end{array}$ & p-value \\
\hline Benign & $1.8: 1$ & $12-92$ & $49.2 \pm 17.8$ & $48.9 \pm 17.9$ & $49.7 \pm 17.7$ & 0.735 * \\
\hline Malignant & $1.5: 1$ & $9-94$ & $58.5 \pm 20.1$ & $55.9 \pm 20.6$ & $62.5 \pm 19.0$ & 0.136 * \\
\hline All & $1.7: 1$ & $9-94$ & $51.9 \pm 18.9$ & $50.8 \pm 18.9$ & $53.7 \pm 19.0$ & 0.202 * \\
\hline
\end{tabular}

* No difference in the Student's t-test, at 0.05 significance level.

Table 2

Frequency distribution of benign and malignant salivary gland tumors according to site and gender.

\begin{tabular}{|c|c|c|c|c|c|c|c|c|c|c|}
\hline \multirow[t]{4}{*}{ Site } & \multicolumn{10}{|c|}{ Tumor group } \\
\hline & \multicolumn{4}{|c|}{ Benign tumor $(n=215)$} & \multicolumn{4}{|c|}{ Malignant tumor $(n=88)$} & \multirow{2}{*}{\multicolumn{2}{|c|}{$\begin{array}{l}\text { All tumors } \\
(\mathrm{N}=303)\end{array}$}} \\
\hline & \multicolumn{2}{|c|}{ Females $(n=138)$} & \multicolumn{2}{|c|}{ Males $(n=77)$} & \multicolumn{2}{|c|}{ Females $(n=53)$} & \multicolumn{2}{|c|}{ Males $(n=35)$} & & \\
\hline & $\mathbf{n}$ & $\%$ & n & $\%$ & n & $\%$ & $\mathbf{n}$ & $\%$ & $\mathbf{n}$ & $\%$ \\
\hline \multicolumn{11}{|l|}{ Major salivary gland } \\
\hline Parotid & 112 & 81.1 & 59 & 76.6 & 26 & 49.0 & 23 & 65.7 & 220 & 72.6 \\
\hline Submandibular & 20 & 14.5 & 13 & 16.9 & 7 & 13.3 & 6 & 17.1 & 46 & 15.2 \\
\hline Total & 132 & 95.6 & 72 & 93.5 & 33 & 62.3 & 29 & 82.8 & 266 & 87.8 \\
\hline Minor salivary gland & 6 & 4.4 & 5 & 6.5 & 20 & 37.7 & 6 & 17.2 & 37 & 12.2 \\
\hline
\end{tabular}

pleomorphic adenoma and fixed attachment in mucoepidermoid carcinoma.

Average tumor size and duration were compared between benign and malignant tumors. The $\mathrm{p}$-value for tumor size was 0.013 . Average size of benign and malignant tumors was 3.11 and $3.79 \mathrm{~cm}$, respectively. Average duration for benign and malignant groups was 2.81 and 1.80 years, respectively, considering a p-value of 0.039 .

The presence of regional metastasis was only observed in malignant major salivary gland tumors, while distant metastasis was recorded in just one malignant minor salivary gland tumor.

\section{Discussion}

The present study details the profile of individuals with minor and major epithelial salivary gland tumors in Natal. A total of 303 salivary gland tumors were evaluated and several of the epidemiological findings on salivary gland tumors observed are quite similar to those reported for other Brazilian states and worldwide: benign tumors were the most frequent 2,8,9; they were more common in females $2,10,11$, with the parotid gland most affected 2,8,10,12,13; the most common histological variants were pleomorphic adenoma 2,9,12,14,15 and mucoepidermoid carcinoma 2,9; malignant tumors affecting older individuals 2,10,16,17.

Other relevant data were also found in the present research: in the several clinical variables examined, only consistency was statistically associated with histological diagnosis, when benign and malignant tumors are considered separately. If the tumors are considered jointly, ulceration and consistency also show an association. In this study, mucoepidermoid carcinoma presented as a hard mass with fixed attachment. We found no association in any other tumors, corroborating studies by Ansari ${ }^{3}$. Benign tumors were found to be significantly smaller than malignant tumors and disease duration was significantly longer for benign tumors. Regional and distant metastasis are important clinical signs of malignancy 5,6, but in our study, this was rarely observed. 
Frequency distribution of salivary gland tumors according to histopathological diagnosis.

\begin{tabular}{|c|c|c|c|c|c|}
\hline & \multirow{2}{*}{$\begin{array}{c}\text { Parotid } \\
n\end{array}$} & \multirow{2}{*}{$\begin{array}{c}\text { Submandibular } \\
\text { n }\end{array}$} & \multirow{2}{*}{$\begin{array}{c}\text { Minor salivary } \\
\text { gland } \\
n\end{array}$} & \multicolumn{2}{|c|}{ All $(N=303)$} \\
\hline & & & & $\mathrm{n}$ & $\%$ \\
\hline \multicolumn{6}{|l|}{ Benign tumors } \\
\hline \multicolumn{6}{|l|}{ Histopathological diagnosis } \\
\hline Pleomorphic adenoma & 129 & 33 & 9 & 171 & 56.4 \\
\hline Basal cell adenoma & 22 & - & 2 & 24 & 7.9 \\
\hline Warthin's tumor & 16 & - & - & 16 & 5.3 \\
\hline Oncocytoma & 3 & - & - & 3 & 1.0 \\
\hline Myoepithelioma & 1 & - & - & 1 & 0.3 \\
\hline \multicolumn{6}{|l|}{ Malignant tumors } \\
\hline Carcinoma ex pleomorphic adenoma & 1 & 1 & - & 2 & 0.7 \\
\hline Mucoepidermoid carcinoma & 21 & 4 & 17 & 42 & 13.9 \\
\hline Acinic cell carcinoma & 9 & - & - & 9 & 3.0 \\
\hline Adenoid cystic carcinoma & 7 & 6 & 3 & 16 & 5.3 \\
\hline Polymorphic adenocarcinoma & 1 & - & 3 & 4 & 1.3 \\
\hline Cystadenocarcinoma & 1 & - & - & 1 & 0.3 \\
\hline Epithelial myoepithelial carcinoma & 4 & - & - & 4 & 1.3 \\
\hline Adenocarcinoma & 5 & 2 & 3 & 10 & 3.3 \\
\hline Total & 220 & 46 & 37 & 303 & 100.0 \\
\hline
\end{tabular}

Table 4

Results of tests for association ( $p$-value) between histopathological diagnosis and signs and symptoms in each tumor group (benign, malignant and all tumors).

\begin{tabular}{lccc}
\hline Signs and symptoms & Benign & Malignant & All tumors \\
\hline Pain & 0.702 & 0.840 & 0.122 \\
Ulceration & 0.999 & 0.885 & 0.049 \\
Growth & 0.683 & 0.612 & 0.235 \\
Consistency & 0.202 & 0.015 & $<0.001$ \\
Attachment & 0.206 & 0.777 & $<0.001$ \\
\hline
\end{tabular}

Note: the chi-square test $\left(\chi^{2}\right)$ was used.

\section{Conclusions}

The data presented here corroborate a number of previous studies and are therefore relevant to understanding the diverse characteristics exhibited by these tumors. Our clinical aspects and histological findings suggest possible associations. New studies are needed to help elucidate this matter. 


\section{Resumo}

Neoplasias de glândulas salivares são notáveis pela sua diversidade histológica e vários estudos apontam para sua ocorrência variada na população. Aspectos clínicos foram histologicamente avaliadas para determinar sua possível associação e definir parâmetros para diferenciar tumores benignos e malignos. Os arquivos de casos diagnosticados como tumores epiteliais de glândulas salivares, entre 1989 e 2005 foram revistos. A maioria (71\%) dos 303 tumores de glândula salivar estudados eram benignos e o adenoma pleomórfico foi o mais comum. As idades médias para pacientes com tumores benignos e malignos foi de 49,2 e 58,5 anos, respectivamente. Diferença estatisticamente significativa entre estes tumores foi observado para as seguintes variáveis: idade média, o tamanho do tumor e duração da doença. Uma correlação foi encontrada entre o diagnóstico histológico e consistência do tumor. Os dados aqui apresentados corroboram uma série de estudos anteriores e, portanto, são relevantes para entender as diversas características exibidas por estes tumores.

Neoplasias das Glândulas Salivares; Glândulas Salivares; Neoplasias; Saúde do Adulto

\section{Contributors}

M. L. S. A. Morais and A. L. L. Costa participated in the design, the project, analysis and interpretation of data, writing the article, a critical revision of intellectual content and final approval. P. R. Azevedo, C. H. Carvalho and L. Medeiros participated in the design, the project and data analysis and interpretation. T. Lajus participated in writing the article, a critical review of its intellectual content and final approval of the article.

\section{References}

1. Instituto Nacional de Câncer. Incidência de câncer no Brasil. http://www.inca.gov.br/estimativa2010 (accessed on 11/Jan/2011).

2. Pires FR, Pringle GA, Almeida OP, Chen SY. Intra-oral minor salivary gland tumors: a clinicopathological study of 546 cases. Oral Oncol 2007; 43:463-70.

3. Ansari MH. Salivary gland tumors in an Iranian population: a retrospective study of 130 cases. J Oral Maxillofac Surg 2007; 65:2187-94.

4. Jones AV, Craig GT, Speight PM, Franklin CD. The range and demographics of salivary gland tumours diagnosed in a UK population. Oral Oncol 2008; 44:407-17.

5. Subhashraj K. Salivary gland tumors: a single institution experience in India. Br J Oral Maxillofac Surg 2008; 46:635-8.

6. Licitra L, Grandi C, Prott FJ, Schornagel JH, Bruzzi P, Molinari R. Major and minor salivary glands tumours. Crit Rev Oncol Hematol 2003; 45:215-25.
7. Barnes L, Eveson JW, Reichart PA, Sidransky D, editors. Pathology and genetics of head and neck tumours. Lyon: Iarc Press; 2005.

8. Buchner A, Merrel PW, Carpenter WM. Relative frequency of intra-oral minor salivary gland tumors: a study of 380 cases from northern California and comparison to reports from other parts of the world. J Oral Pathol Med 2007; 36:207-14.

9. Yib WY, Kratochvil FJ, Stewart JC. Intraoral minor salivary gland neoplasms: review of 213 cases. J Oral Maxillofac Surg 2005; 63:805-10.

10. Wang D, Li Y, He H, Liu L, Wu L, He Z. Intraoral minor salivary gland tumors in a Chinese population: a retrospective study on 737 cases. Oral Surg Oral Med Oral Pathol Oral Radiol Endod 2007; 104:94-100.

11. Ito FA, Ito K, Vargas PA, Almeida OP, Lopes MA. Salivary gland tumors in a Brazilian population: a retrospective study of 496 cases. Int J Oral Maxillofac Surg 2005; 34:533-6. 
12. Jaber MA. Intraoral minor salivary gland tumors: a review of 75 cases in a Libyan population. Int J Oral Maxillofac Surg 2006; 35:150-4.

13. Lopes MA, Kowalski LP, Santos GC, Almeida OP. A clinicopathologic study of 196 intraoral minor salivary gland tumours. J Oral Pathol Med 1999; 28:264-6.

14. Copelli C, Bianchi B, Ferrari S, Ferri A, Sesenna E. Malignant tumors of intraoral minor salivary glands. Oral Oncol 2008; 44:658-66.

15. Tian Z, Li L, Wang L, Hu Y, Li J. Salivary gland neoplasms in oral and maxillofacial regions: a 23-year retrospective study of 6982 cases in an eastern Chinese population. Int J Oral Maxillofac Surg 2010; 39:235-42.
16. Dhanuthai K, Boonadulyarat $\mathrm{M}$, Jaengjongdee $\mathrm{T}$, Jiruedee K. A clinico-pathologic study of 311 intraoral salivary gland tumors in Thais. J Oral Pathol Med 2009; 38:495-500.

17. Tilakaratne WM, Jayasooriya PR, Tennakoon TMPB, Saku T. Epithelial salivary tumors in Sri Lanka: a retrospective study of 713 cases. Oral Surg Oral Med Oral Pathol Oral Radiol Endod 2009; 108:90-8.

Submitted on $31 / \mathrm{Jul} / 2010$

Final version resubmitted on 19/Feb/2011

Aproved on 24/Feb/2011 